\title{
Evaluation of Crude Oil Biodegradation Efficiency and Peroxidase Production by Streptomyces albus
}

\author{
*EHIOSUN, KI; USMAN, M \\ Biochemistry Department, Edo University, Iyamho, Edo State, Nigeria \\ *Email: ehiosun.kevin@edouniversity.edu.ng
}

\begin{abstract}
The disadvantages associated with conventional treatment of crude oil pollution have led to the development of alternative, economical and reliable biological treatments. In this study, six actinobacterial isolates were obtained from $120 \mathrm{~cm}$ soil depth of a selected crude oil contaminated site in the Niger Delta region of Nigeria. Streptomyces albus was selected from the six isolates based on its comparative ability to growth on crude oil and was investigated for its ability to degrade varying concentration of crude oil $(1.0,3.0,5.0$ and $7.5 \%)$ and produce peroxidase during the biodegradation period. Increase in biomass enhanced degradation efficiency above $80 \%$ after 10 days for all concentration of crude oil studied. Peroxidase production increased maximally during the $\log$ phase of growth with a maximum production of (3.01 U/L) on day 10 for $3 \%$ crude oil and $(2.08 \mathrm{U} / \mathrm{L})$ for $5 \%$ crude oil medium on day 12 . These remarkable properties displayed by Streptomyces albus in this study showed how tolerant and efficient this actinobacterial isolate was toward varying concentration of crude oil vis-à-vis the production of peroxidase.
\end{abstract}

DOI: https://dx.doi.org/10.4314/jasem.v22i2.10

Copyright: Copyright (C) 2018 Omorogieva and Imasuen. This is an open access article distributed under the Creative Commons Attribution License (CCL), which permits unrestricted use, distribution, and reproduction in any medium, provided the original work is properly cited

Dates: First received 01 August 2017; Received in revised form 16 January 2018; Accepted 10 February 2018

Keywords: Biodegradation, Peroxidase, crude oil, Bioremediation, Streptomyces albus

Crude oil pollution has caused critical environmental and health defects (Obayori et al., 2009b, Muthuswamy et al., 2008). Bioremediation methods are the preferred environmental friendly treatment technologies for the remediation of hydrocarbons because of its low cost and complete removal of crude oil without introduction of secondary pollution when compared to the conventional methods of remediation (Jinlan, 2012). Actinobacteria have several characteristics that are essential for bioremediation: they are excellent metabolizers, with the ability to survive extreme conditions and produce biosurfactants which increase contaminant bioavailability and facilitate biodegradation process (Lin et al., 2010). Characterization of actinobacterial populations living in crude oil contaminated soils and evaluation of their degradation capacities serve as a guide for improving remediation of such environments (van Hamme et al., 2003; Zhengzhi et al., 2010). The detoxification of toxic organic compounds by various bacteria and fungi (Gianfreda et al, 1999) through oxidative coupling is mediated by oxidoreductases such as peroxidase. During such oxidation-reduction reactions, the contaminants are finally oxidized to harmless compounds (ITRC, 2002). This study was aimed at investigating the crude oil biodegradation capability of Streptomyces albus isolated from a crude oil contaminated soil and the role of total peroxidase in the crude oil degradation process.

\section{MATERIALS AND METHODS}

Soil collection: Soil sample was collected at $120 \mathrm{~cm}$ depth from ground surface of crude oil spilled site into a clean plastic container.

Microbial isolation, characterization and identification: Actinobacterial isolation, characterization and identification were carried out according to Bergey's Manual of Systematic Bacteriology (Whitman et al., 2012).

Screening of actinobacteria capable of utilizing crude oil: In order to select best crude oil degrader, 5 $\%$ seed culture inoculum were aseptically used to inoculate mineral salts medium $\left(\mathrm{NH}_{4} \mathrm{NO}_{3}(2.0 \mathrm{~g} / \mathrm{L})\right.$, $\mathrm{KH}_{2} \mathrm{PO}_{4}(0.2 \mathrm{~g} / \mathrm{L}), \mathrm{KH}_{2} \mathrm{PO}_{4} .12 \mathrm{H}_{2} \mathrm{O}(0.2 \mathrm{~g} / \mathrm{L}), \mathrm{NaCl}$ $(0.8 \mathrm{~g} / \mathrm{L}), \mathrm{KCl}(0.8 \mathrm{~g} / \mathrm{L}), \mathrm{CaCl}_{2} \cdot 2 \mathrm{H}_{2} \mathrm{O}(0.1 \mathrm{~g} / \mathrm{L})$, $\mathrm{MgSO}_{4}(0.2 \mathrm{~g} / \mathrm{L})$ and $\left.\mathrm{FeSO}_{4} .7 \mathrm{H}_{2} \mathrm{O}(0.002 \mathrm{~g} / \mathrm{L})\right)$ with crude oil $(10 \mathrm{~g} / \mathrm{L})$ at $\mathrm{pH} 7.4$. These were incubated in an orbital shaker at $180 \mathrm{rpm}$ at $30{ }^{\circ} \mathrm{C}$ for a period of 7 days. Growth was monitored through culture optical density at $620 \mathrm{~nm}$ (Muthuswamy et al., 2008). The isolate with highest growth profile was selected for further studies while $1 \%$ glucose-based medium was used as control. 


\begin{tabular}{|c|c|c|c|c|c|c|c|}
\hline & & Colour & & & & & \\
\hline & & $\begin{array}{l}\text { Waibs } \\
\text { puvdezy }\end{array}$ & $\begin{array}{l}\text { Cxustu } \\
\text { Visize }\end{array}$ & $\begin{array}{l}\text { Guyicle } \\
\text { pinkish }\end{array}$ & Waibs & $\begin{array}{l}\text { Cxusmi wriks } \\
\text { mycelis }\end{array}$ & $\begin{array}{l}\text { Crunzu } \\
\text { vicize }\end{array}$ \\
\hline $\begin{array}{l}\text { Rosplaslugical } \\
\text { Toot }\end{array}$ & $\begin{array}{l}\text { Gram reaction } \\
\text { Cellular } \\
\text { morphology }\end{array}$ & $\vec{R} \propto d s$ & $\begin{array}{l}\text { Coccoid } \\
\text { rod }\end{array}$ & $\begin{array}{l}+ \\
\text { Coccoid } \\
\text { red }\end{array}$ & $\begin{array}{l}\dot{T} \\
\text { Rods }\end{array}$ & $\bar{R} \propto \mathrm{ds}$ & $\begin{array}{l}+ \\
\text { Coccoi } \\
d \text { rod }\end{array}$ \\
\hline \multirow{20}{*}{$\begin{array}{l}\text { Ilochemesl } \\
\text { Test }\end{array}$} & Calalase test & - & - & - & - & - & - \\
\hline & $\begin{array}{l}\text { Oridaos toot } \\
\text { Indole test } \\
\text { Matility toat } \\
\text { Mathyt rad tast } \\
\text { Vozca Frolacuar } \\
\text { Teat }\end{array}$ & - & $\begin{array}{l}- \\
-\end{array}$ & $\begin{array}{l}- \\
-\end{array}$ & $\begin{array}{l}- \\
-\end{array}$ & $\dot{.}$ & - \\
\hline & Catatentiluation & - & - & - & - & - & - \\
\hline & Irease sctiviz & - & - & + & - & - & + \\
\hline & Starch hydrolyn is & - & - & - & + & - & - \\
\hline & $\begin{array}{l}\text { Gelatin } \\
\text { mydmiysis }\end{array}$ & - & - & - & - & + & + \\
\hline & rasain & - & + & - & + & + & + \\
\hline & hymenty yovis. & & & & & & \\
\hline & NOrmblation & + & - & + & + & - & + \\
\hline & Glucose & + & + & + & + & + & + \\
\hline & Sucrose & + & + & + & + & - & - \\
\hline & Arhimes & + & - & - & + & - & - \\
\hline & Malthen & 1 & - & 1 & - & - & - \\
\hline & Mannited & + & + & + & - & + & + \\
\hline & $x_{y} 100$ & + & + & - & + & + & - \\
\hline & Galuctore & + & - & - & - & - & - \\
\hline & Raffinou & - & - & I & I & - & 1 \\
\hline & Saxcin & + & & & + & + & \\
\hline & Sorbitol & & + & & + & & + \\
\hline & Lactoos & + & + & & & + & + \\
\hline $\begin{array}{l}\text { Mfiamobinl } \\
\text { Iducity }\end{array}$ & $\begin{array}{c}\text { Masobial } \\
\text { 3ywivo }\end{array}$ & 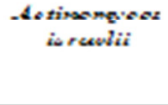 & 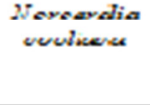 & $\begin{array}{l}\text { Nevesedia } \\
\text { upuese }\end{array}$ & 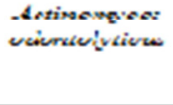 & $\begin{array}{c}\text { Stroptemenos } \\
\text { cllwe }\end{array}$ & $\begin{array}{c}\text { Nevear } \\
\text { dice } \\
\text { brarilio } \\
\text { novos }\end{array}$ \\
\hline
\end{tabular}

Crude oil biodegradation study: Biodegradation of varying crude oil concentration: Streptomyces albus was used to carry out the biodegradation of $1,3,5$, and $7.5 \%$ crude oil-based media using $5 \%$ seed culture inocula incubated in an orbital shaker at $180 \mathrm{rmp}$ at $30{ }^{0} \mathrm{C}$ for a period of time. Growth, residual crude oil, total peroxidase production and degradation efficiency were monitored. A Blank was prepared, which consisted of sterilized crude oil media in the absence of active actinobacteria.

Determination of residual crude oil and degradation efficiency: The residual crude oil in the treatment were determined spectrophotometrically (Odu et al., 1985) at 2 days interval. Samples (5 $\mathrm{mL}$ ) from different treatments were mixed vigorously using a vortex mixer with equal volume of toluene to extract hydrocarbons from the samples. The extracted crude oil was detected at $420 \mathrm{~nm}$. A blank was prepared, which consisted of distilled water without crude oil. A standard curve was also prepared using known concentration of crude oil to estimate the amount of crude oil in the samples. Residual crude was estimated as the difference between the initial and final concentrations of crude oil and degradation efficiency was estimated in percentage.

Determination of peroxidase production: Total peroxidase activity was observed with modification every 2 days via oxidation of $0.24 \mathrm{mM}$ 2,2'azino-di-[3 ethyl benzothiazoline-6-sulphonic acid] (ABTS) buffered with $50 \mathrm{mM}$ sodium acetate buffer $(\mathrm{pH} 5)$ in the presence of 5 $\mathrm{mM} \mathrm{H}_{2} \mathrm{O}_{2}$ at $414 \mathrm{~nm}$ for 5 minutes in a spectrophotometer (Hunter et al., 2003). The reaction mixture ( $3 \mathrm{~mL}$ ) contains $1 \mathrm{~mL}$ ABTS, $1 \mathrm{~mL}$ of culture filtrate and $1 \mathrm{~mL} \mathrm{H}_{2} \mathrm{O}_{2}$. The fermentation broths were earlier centrifuged at $5000 \mathrm{rpm}$ for 20 minutes using refrigerated centrifuge at $4{ }^{0} \mathrm{C}$ to obtain a clear supernatant. One unit (U) of total peroxidase activity was defined as the amount of enzyme oxidizing $1 \mu \mathrm{mol}$ ABTS per minute at $\mathrm{pH} 5.0$ and $30{ }^{\circ} \mathrm{C}$ with a molar extinction coefficient for the ABTS radical cation (the reaction product) of $\varepsilon 414 \mathrm{~nm}=31100 \mathrm{M}^{-1} \mathrm{~cm}^{-1}$.

\section{RESULTS AND DISCUSSION}

Actinobacteria isolation,

characterization and identification:

Six Actinobacterial isolates were isolated from $120 \mathrm{~cm}$ soil depth. Identification of the isolates was based on morphological and biochemical characterization as presented in Tables 1.

Screening of actinobacterial isolates: The six actinobacterial isolates screened had varied degree of growth in the crude oil-based medium (figure $1)$. 

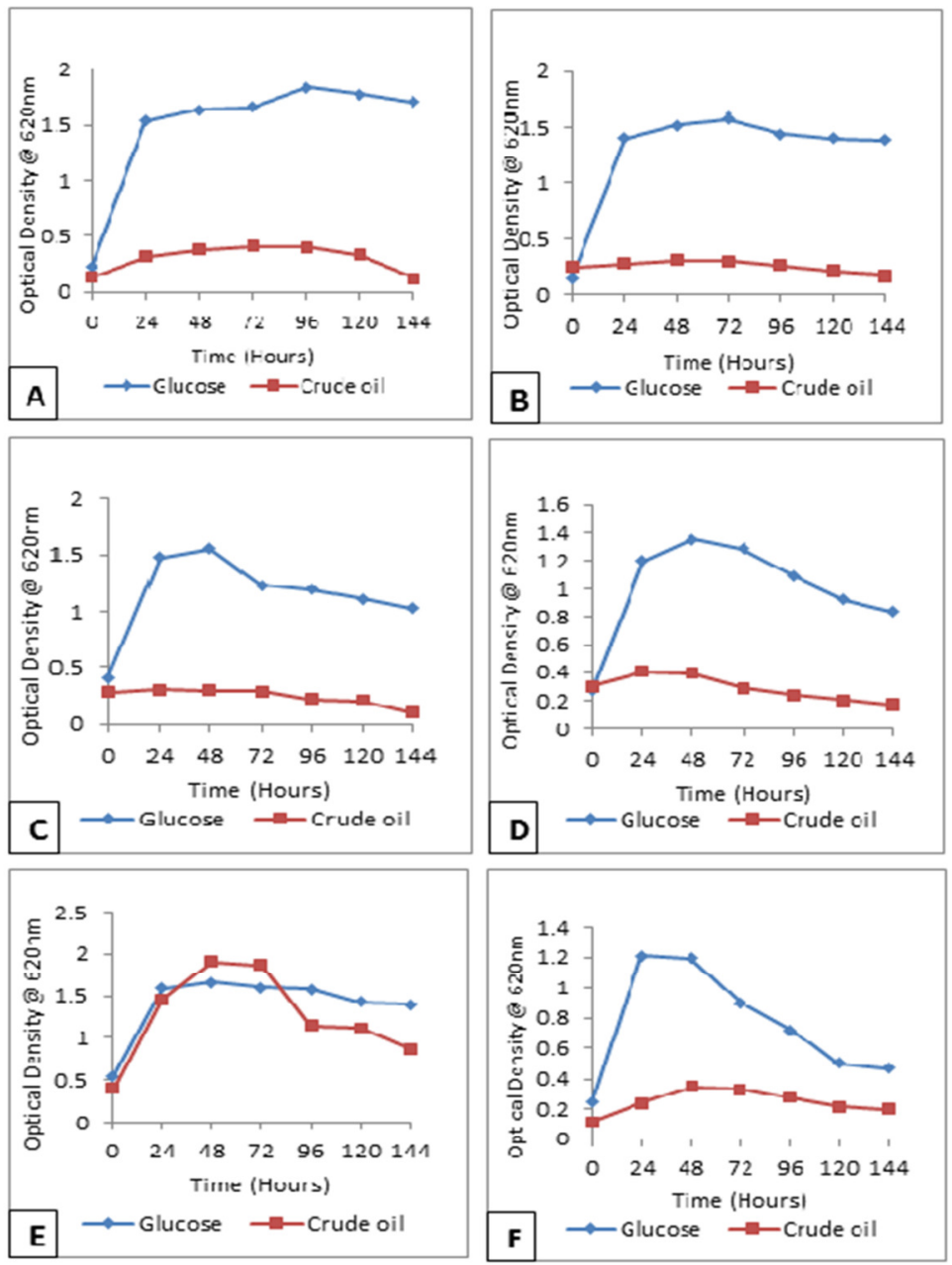

Fig 1: Growth profile of (A) Actinomyces israelii, (B) Norcardia coeliaca, (C) Norcardia opaca, (D) Actinomyces odontolyticus, (E) Streptomyces albus and (F) Norcardia brasiliences on $1 \%$ Glucose and Crude oil based medium

The actinobacterial growth profile for all isolates showed that glucose was readily utilized within 48 hours. However, a prolonged lag phase was exhibited by the isolates in the crude oil medium except for Streptomyces albus (Figure 1E). Therefore, Streptomyces albus was selected for further studies. Microorganisms preferentially metabolize glucose than substrates such as crude oil because it is more energy efficient because of the simpler structure of glucose. The main sources of carbon for microorganisms in crude oil are hydrocarbons and organic compounds that are often the products of crude oil biodegradation (Dandie et al., 2004). Streptomyces albus growth profile and crude oil degradation: High rate of crude oil degradation was observed during the log phase of growth of the isolate with more than $50 \%$ of crude oil degraded (figure 2). Streptomyces albus exhibited no lag phase in the presence of $1 \%$ crude oil with residual crude oil of $0.49 \%$ on day 2 (figure $2 \mathrm{~A}$ ). The residual crude oil decreased to as low as $0.023 \%$ on the twelfth day. Similarly, a report by Olajuyigbe and Ehiosun (2016) showed Actinomyces viscosus and Actinomyces israelii had degraded $87 \%$ and $80 \%$, respectively of initial crude oil without inhibitory influence on their growth. During biodegradation of $3 \%$ crude oil, stationary phase set in on day 6 resulting to a slow declining phase on day 8 with reduction in crude oil biodegradation rate. The findings of George-Okafor et al. (2000) have showed that Aspergillus versicolor and Aspergillus niger exhibited biodegradation efficiency higher than 98\% while Mance et al. (2007) reported $86 \%$ and $81 \%$ for Penicillium funiculosum and Aspergillus sydowii, respectively after 120 days. Streptomyces albus exhibited no lag phase of growth in $5 \%$ crude oil although there was a quick onset of stationary phase on day 4 of the study. The residual crude oil further dropped to $0.52 \%$ after day 12 (figure 2C). Further study with $7.5 \%$ crude oil showed that $S$. albus also exhibited low growth with an early and prolonged stationary phase from day 6 . Streptomyces albus exhibited high growth profile and biodegradation rate because the branching filamentous mode of growth allows for more efficient colonization and exploration of the crude oil (Hamman, 2004), production of biosurfactants and adaptation to nutrient limited conditions consequently do not fluctuate in response to hydrocarbon enrichment (Quatrini et al., 2008) which normally causes nutrient deficiencies (Stroud et al., 2007).

Total peroxidase production and degradation efficiency: An important increase in total peroxidase activity in this study followed by a decrease in crude oil concentration suggest that total peroxidase is involved in crude oil degradation. Microbial growth and production of peroxidase have been reported to be triggered by nutrient (carbon and nitrogen sources) availability (Soni et al., 2012). Peroxidase production increased maximally during the log phase of growth of the isolates under study (figure 3). 

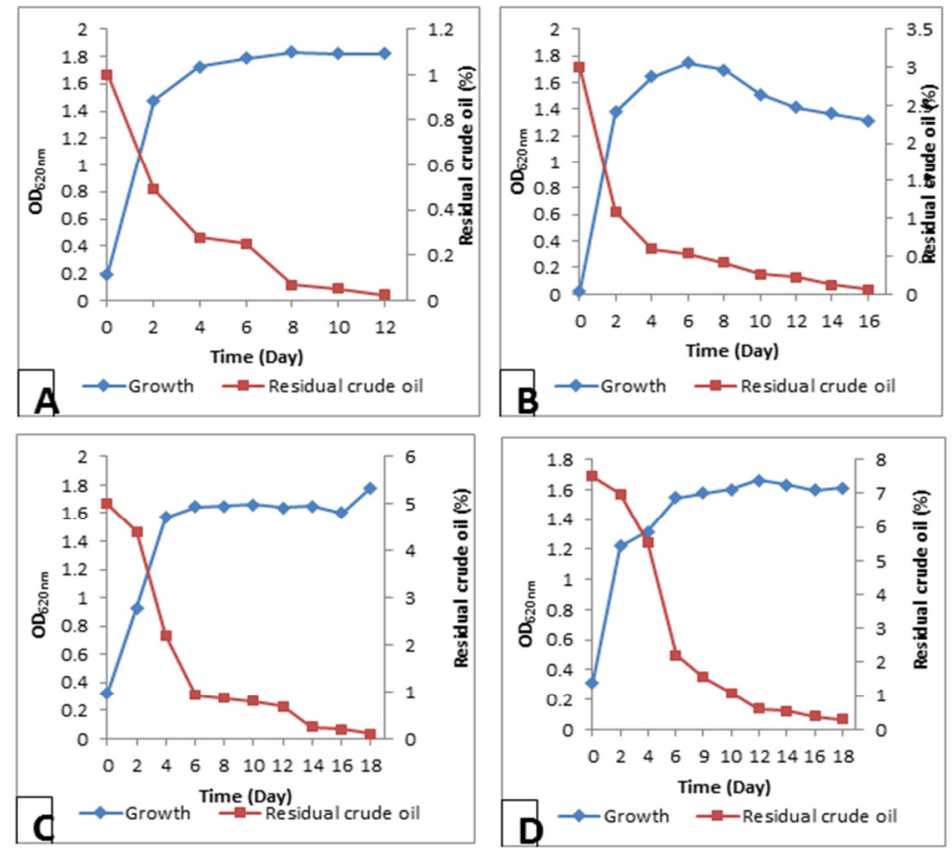

Fig 2: Growth profile and residual crude oil of Streptomyces albus in (A) 1\%, (B) 3\%, (C) $5 \%$, (D) $7.5 \%$ crude oil based medium
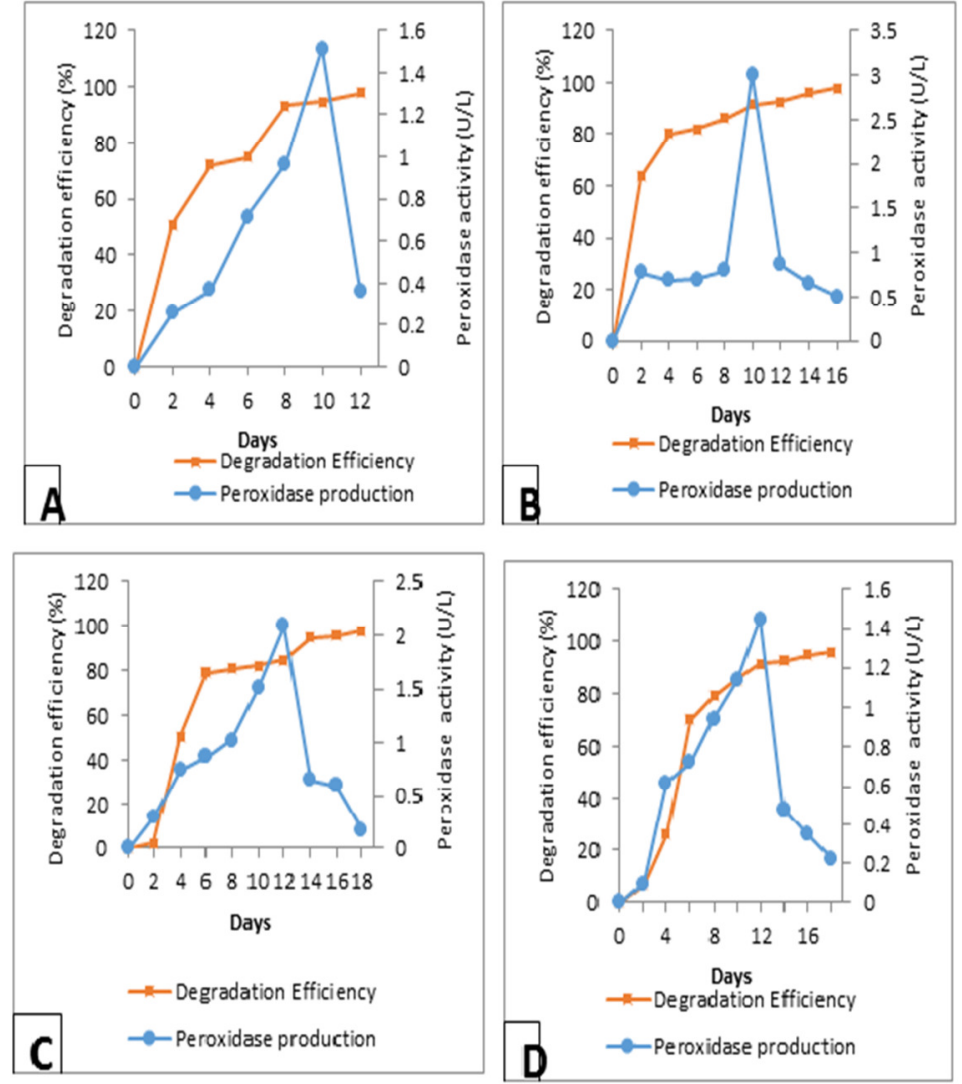

Fig 3: Degradation efficiency and peroxidase production by Streptomyces albus in (a) $1 \%$, (b) $3 \%$, (c) $5 \%$, (d) $7.5 \%$ crude oil based medium.
The enzyme production increased on day 2 to a maximum of $1.51 \mathrm{U} / \mathrm{L}$ and $3.01 \mathrm{U} / \mathrm{L}$ on day 10 by Streptomyces albus on $1 \%$ and $3 \%$ crude oil medium, respectively (figure $3 \mathrm{~A}$ and 3B) with degradation efficiency of $97.97 \%$ on day 16 of the study for $3 \%$ crude oil (figure 3B). Further increase in degradation efficiencies after decline in peroxidase production might be related to the activity of some intracellular enzymes involved in crude oil degradation as reported by Olajuyigbe and Ehiosun (2016). However, Streptomyces albus exhibited enzyme activity with a maximum production on day 12 (2.08 U/L) for $5 \%$ crude oil medium with biodegradation efficiency of $84.90 \%$ (figure 3C). Meanwhile, it was observed that the biodegradation efficiency was $92.59 \%$ on day 14 in $7 \%$ with peroxidase activity of 1.45 U/L (figure 3D). Comparably, Lateef et al. (2011) have also reported more than $90 \%$ degradation of Bonny Light crude oil (1 g/L) by two Pseudomonas isolates but over a period of 21 days. The measurement of high activity levels of peroxidase, coupled with the removal of crude oil may be considered to be indicative of a relationship between enzymes activity and degradation yield (Anastasi et al., 2009).

Conclusion: Crude oil pollution is a major threat to the environment as they adversely affect the surrounding ecosystem. The microorganisms present at oil contaminated sites have ability to degrade toxic contaminants present in crude oil into nontoxic forms. The remarkable properties displayed by Streptomyces albus in this research showed how tolerant and efficient this actinobacterial isolate was toward varying concentration of crude oil visà-vis the production of peroxidase. Hence, Streptomyces albus is a good biotechnological tool for crude oil biodegradation. 


\section{REFERENCE}

Anastasi, A; Coppola, T; Prigionea, V; Varesea, G (2009). Pyrene degradation and detoxification in soil by a consortium of basidiomycetes isolated from compost: Role of laccases and peroxidases. $J$. Hazard. Mat. 165: 1229-1233.

Dandie, CE; Thomas, SM; Bentham, RH; McClure, NC (2004). Physiological characterization of Mycobacterium sp. strain 1B isolated from a bacterial culture able to degrade high-molecularweight polycyclic aromatic hydrocarbons. J. Appl. Microbiol.97:246-255

George-Okafor, U; Tasie, F; Okafor, FM (2000). Hydrocarbon degradation potentials of indigenous fungal isolates from petroleum contaminated soils. Physical Nature Sci. 3(1): 1-6.

Gianfreda, L; Xu, F; Bollag, JM (1999). Laccases: a useful group of oxidoreductive enzymes, Bioremediation Journal 3(1):1-25.

Hamman, S (2004). Bioremediation capabilities of whiter rot fungi. Biodegradation 52:1-5

Hunter, CL; Maurus, R; Mauk, MR; Lee, H; Raven, EL; Tong, H; Nguyen, N; Smith, M; Brayer, GD; Mauk, AG (2003). Introduction and characterization of a functionally linked metal ion binding site at the exposed heme edge of myoglobin. PNAS 100(7): 3647-3652.

Lateef, BS; Oluwafemi, SO; Omokorede, SA; Genevieve, OO (2011). Biodegradation of Bonny Light Crude Oil by Bacteria Isolated from Contaminated Soil. Inter. J. Agric. Biol. 13(2):245250 .

Lin, TC; Pan, PT; Cheng, SS (2010). Ex situ bioremediation of oil-contaminated soil, J. Hazard. Mat. 176(1-3):27-34.

Mance a-Lopez, ME; Rodriguez, MT; Rios-Leal, E; Esparza-Carcia, F; Chavez- Gommez, B; Rodriguez- Vazques, R; Barrera-Cortes, J (2007). Fungi and bacteria isolated from two highly polluted soils for hydrocarbon degradation. J. Acta Chimica Slovenica 54: 201-209.

Muthuswamy, S; Arthur, RB; Sang-Ho, B; Sei-Eok Y (2008). Biodegradation of crude oil by individual bacterial strains and a mixed bacterial consortium isolated fromhydrocarbon contaminated areas. Clean 36:92-96.
Obayori, OS; Ilori, MO; Adebusoye, SA; Oyetibo, GO; Omotayo, AE; Amund, OO (2009). Degradation of hydrocarbons and biosurfactant production by Pseudomonas sp. strain LP1. World J. Microbiol. Biotechnol. 25: 1615-1623

Odu, CTI; Esuruoso, OF; Nwoboshi, LC; Ogunwale, JA (1985). Environmental Study of the Nig. Agip Oil Company, Operational Area. Soil and Fresh Water Vegetation. Union Graft publs. Milan 1:22-25

Olajuyigbe, FM; Ehiosun, KI (2016). Assessment of crude oil degradation efficiency of newly isolated actinobacteria reveals untapped bioremediation potentials. Bioremediation Journal 20(2):133-143.

Quatrini, P; Scaglione, G; De Pasquale, C; Reila, S; Puglia, AM (2008). Isolation of Gram-positive nalkane degraders from a hydrocarbon contaminated Mediterranean shoreline. J. Appl. Microbiol. 104: 251-259.

Radwan, SS; Barabas, GY; Sorkhoh, NA; Damjanovich, S; Szabo, I; Matko, J; Penyige, A; Hirano, T; Szabo I.M (1998). Hydrocarbon uptake by Streptomyces. FEMS Microbiol. Letters, 169:87-94.

Rahman, KSM; Rahman, JT; Lakshmanaperumalsamy, P; Banat, IM (2002). Towards Efficient Crude Oil Degradation by a Mixed Bacterial Consortium, Biores.. Technol. 85:257 - 261 .

Stroud, JL; Paton, GI; Semple, KT (2007). Microbealiphatic hydrocarbon interactions in soil; implications for biodegradation and bioremediation. J. Appl. Microbiol. 102: 12391253.

Van Hamme, JD; Singh, A; Ward, OP (2003). Recent advances in petroleum microbiology. Microbiol Mol Biol Rev. 67:503-549.

Whitman, W; Goodfellow, M; Kämpfer, P;Busse, H; Trujillo, ME; Ludwig, W; Suzuki, K; Parte, A Eds. (2012). The Actinobacteria: Bergey's Manual of Systematic Bacteriology. 2nd Edition, SpringerVerlag, UK.

Zhengzhi, Z; Lixue, G; Zhaowei, H; Chunyu, Y; Cuiqing, M; Zhongguo, W; Baiping, S; Xiaofei, H; Hongzhi, T; Ping, X (2010). Characterization and biotechnological potential of petroleum-degrading bacteria isolated from oil-contaminated soils. Biores. Technol. 101. 